ARTICLE

DOI: $10.1038 / \mathrm{s} 41467-018-04480-6$

\title{
Total synthesis of cyrneines A-B and glaucopine C
}

\author{
Guo-Jie Wu1, Yuan-He Zhang ${ }^{1,2}$, Dong-Xing $\operatorname{Tan}^{1,2}$ \& Fu-She Han (1) 1,3
}

The cyrneine diterpenoids represent a structurally intriguing subfamily of cyathane diterpenoids and could significantly induce neurite outgrowth. Therefore, the efficient synthesis of these natural products is of great importance. Herein, we present a route for the collective synthesis of cyrneines A, B, and glaucopine C. As the key precursor, the 5-6-6-tricyclic scaffold is efficiently constructed by employing a mild Suzuki coupling of heavily substituted nonactivated cyclopentenyl triflate and a chelation-controlled regiospecific Friedel-Crafts cyclization as key transformations. The stereoselective installation of the all-carbon quaternary center at $\mathrm{C}_{6}$ ring junction of the tricycle is achieved via Birch reductive methylation. Subsequently, a carbenoid-mediated ring expansion furnishes the essential 5-6-7-tricyclic core. Finally, manipulation of this core by several appropriately orchestrated conversions accomplishes a more step-economic synthesis of cyrneine A (20 steps), and the first synthesis of cyrneine B (24 steps) and glaucopine C (23 steps).

\footnotetext{
${ }^{1}$ Key Lab of Synthetic Rubber, Changchun Institute of Applied Chemistry, Chinese Academy of Sciences, 5625 Renmin Street, Changchun, Jilin 130022 , China. ${ }^{2}$ University of Science and Technology of China, Hefei, Anhui 230026, China. ${ }^{3}$ State Key Lab of Fine Chemicals, Dalian University of Technology, Dalian 116024, China. Correspondence and requests for materials should be addressed to F.-S.H. (email: fshan@ciac.ac.cn)
} 
T he cyathane diterpenoids compose a large family of natural products with greater than 100 members $^{1-3}$. These molecules feature a common 5-6-7 fused tricarbocyclic core with most of which possessing two all-carbon quaternary stereocenters at the ring junctions with anti-orientation. The unique structural framework coupled with the diverse oxidation and unsaturation states around the ring periphery gives rise to the structural complexity and diversity. Biological evaluation revealed that cyathane diterpenoids exhibit a rich variety of biological activities such as antibiotics, antimicrobial, antitumor, antiinflammatory, and most significantly, nerve growth factor (NGF)regulating properties. Over the roughly 20 years, considerable total synthesis efforts have been conducted, and a number of molecules within the subclasses of allocyathin, erinacine, sarcodonin, cyathin, scabronine, and cyanthiwigin have been synthesized in enantioselective or racemic forms. Of note are important contributions from the groups of Nakada ${ }^{2}$, Ward ${ }^{4,5}$, Trost ${ }^{6,7}$, Danishefsky $^{8}$, Stoltz $^{9}$, Phillip $^{10}$, Reddy $^{11}$, Snider $^{12,13}$, and others $^{14,15}$.

The cyrneines $\mathrm{A}-\mathrm{E}$ and glaucopine $\mathrm{C}^{16-19}$, isolated form the Sarcodon Cyrneus, are a novel subfamily of cyathane diterpenoids (Fig. 1a). Unique to the structures of this subfamily as compared with other subclasses ${ }^{2-15}$ is the extra oxidation at $C_{1}$ (e.g., $\mathbf{1}, \mathbf{3}, \mathbf{5}$, and 6), or at both $C_{1}$ and $C_{4}$ (e.g., 2 and 4 ) in the five-membered
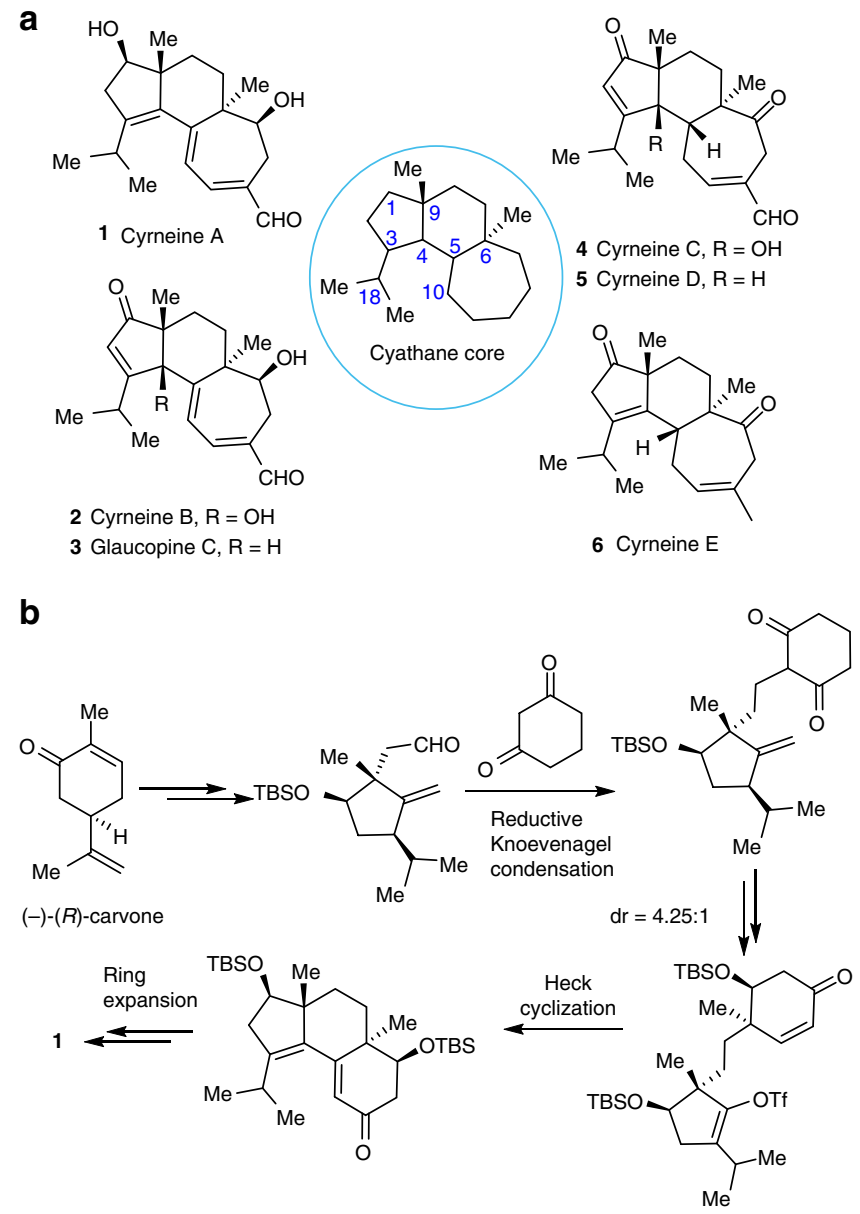

Fig. 1 Cyathane diterpenoid natural products. a The structures of cyrneines A-E and glaucopine C. The [5.6.7]-tricycle highlighted in blue circle indicates a common core structural motif shared by the natural products. $\mathbf{b}$ The key reactions included in Gademann's synthesis of cyrneine A. Me methyl, Tf trifluoromethanesulfonyl, TBS tertiary-butyldimethylsilyl, dr diastereomeric ratio ring. This causes considerable synthetic challenges resulting from the higher oxidation states as well as the increased stereocenters at $\mathrm{C}_{1}$ or $\mathrm{C}_{4}$, especially for compounds 2 and $\mathbf{4}$ bearing an allylic functionality at $\mathrm{C}_{4}$ and two vicinal quaternary centers at $\mathrm{C}_{4}$ and $\mathrm{C}_{9}$ ring junction. To date, only cyrneine A (1) has been synthesized by Gademann and co-workers ${ }^{20}$ with an elegant sequence of 24 steps from (-)-(R)-carvone (Fig. 1b). The key transformations involved a reductive Knoevenagel condensation, a Heck cyclization, and a Yamamoto ring expansion. On the other hand, biological evaluations showed the activity of this subfamily was markedly influenced by the minor structural differences. Among the molecules evaluated, cyrneines A (1) and B (2) could induce significantly the neurite outgrowth in PC12 cells and the expression of NGF in $1321 \mathrm{~N} 1$ cells in a concentration-dependent manner. Thus, driven by the structural complexity, biological potential, and the interest for an in-depth SAR elucidation, it is of great importance to develop a strategically new route that could be used for efficient and versatile synthesis of these natural products and potential analogues. Herein, we report such a route as demonstrated by a more step-economic synthesis of cyrneine A (1), and the first synthesis of cyrneine B (2) and glaucopine C (3).

\section{Results}

Retrosynthetic analysis. We envisioned that the 5-6-7 tricyclic core $\mathbf{A}$ could serve as an advanced intermediate for our divergent synthesis (Fig. 2). The key challenge for accessing cyrneine A (1) and the intermediate $\mathbf{B}$ would be the $\beta$-selective reduction of carbonyl at $\mathrm{C}_{14}$ in A. The glaucopine C (3) and cyrneine B (2)

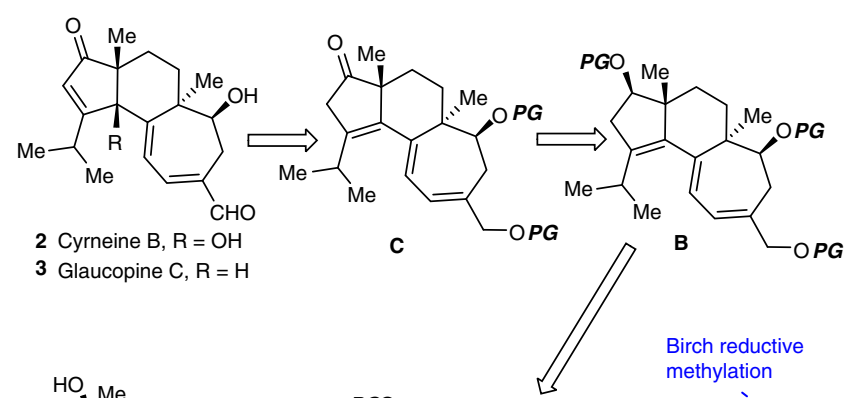

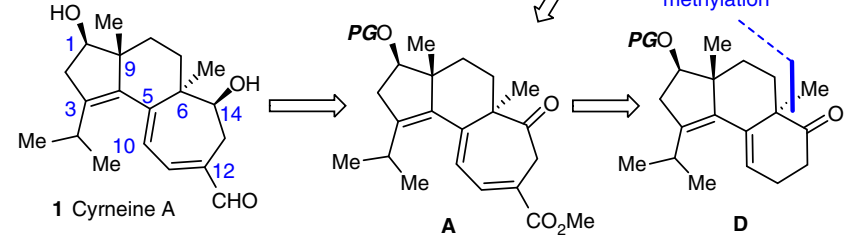
(Advanced intermediate)<smiles>[R]C([R])=CCC1(C)C(=O)CCC1=O</smiles>

Fig. 2 Retrosynthetic analysis of cyrneine A-B and glaucopine C. PG stands for protecting group; $\mathrm{F}-\mathrm{C}$ represents Friedel-Crafts; unless otherwise noted, $\mathrm{R}$ in structures $\mathbf{E}-\mathbf{J}$ indicates hydrogen or methyl group 
were planned to be synthesized from $\mathbf{C}$ by means of 1,3-prototropic shift and $\gamma$-oxidation at $\mathrm{C}_{4}$, albeit numerous concerns such as stereo- as well as regio- and chemoselectivity are appreciably involved in these late-stage manipulations arising from the conjugation effect of multiple olefinic functionalities in the 5- and 7membered ring, and the acidity of proton at $\mathrm{C}_{2}$ and $\mathrm{C}_{18}$. The

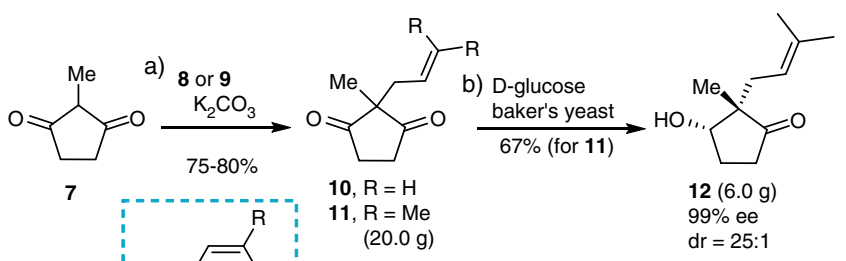

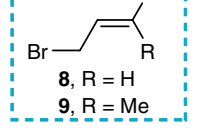

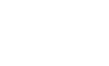

c) $p-\mathrm{NO}_{2}-\mathrm{C}_{6} \mathrm{H}_{4} \mathrm{CO}_{2} \mathrm{H}$ $\mathrm{PPh}_{3}$, DEAD

d) $\mathrm{K}_{2} \mathrm{CO}_{3}, \mathrm{MeOH} / \mathrm{THF}$

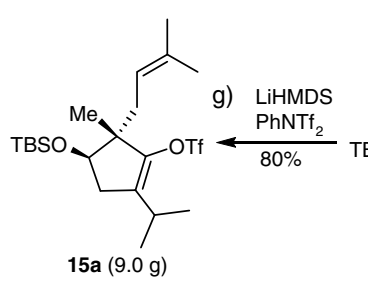

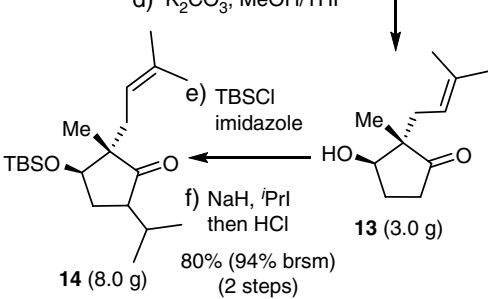

Fig. 3 Synthesis of 15a. Reagents and conditions: (a) 8 or 9 (2.0 equiv), $\mathrm{K}_{2} \mathrm{CO}_{3}$ (1.5 equiv), acetone, rt, overnight (75-80\%); (b) Yeast extract (50 wt\%), D-glucose, dry active baker's yeast, $\mathrm{H}_{2} \mathrm{O}, \mathrm{rt}, 36 \mathrm{~h}(67 \%)$; (c) $p-\mathrm{NO}_{2}-\mathrm{C}_{6} \mathrm{H}_{4} \mathrm{CO}_{2} \mathrm{H}$ (2.0 equiv), $\mathrm{PPh}_{3}$ (2.0 equiv), DEAD (2.0 equiv), THF, $\mathrm{O}$ to $50{ }^{\circ} \mathrm{C}$, overnight (90\%); (d) $\mathrm{K}_{2} \mathrm{CO}_{3}$ (2.0 equiv), $\mathrm{MeOH} / \mathrm{THF}(\mathrm{v} / \mathrm{v}=1: 2)$, $0^{\circ} \mathrm{C}, 30 \mathrm{~min}$ (98\%); (e) TBSCl (1.2 equiv), imidazole (1.2 equiv), DMF, rt, overnight (91\%); (f) $\mathrm{NaH}$ (5.0 equiv), iPrl (10.0 equiv), THF, reflux, overnight; then aq. $\mathrm{HCl}(2 \mathrm{M}), \mathrm{rt}, 1.5 \mathrm{~h}(88 \%)$; (g) LiHMDS (1.3 equiv, $1.0 \mathrm{M}$ in THF), $\mathrm{PhNTf}_{2}$ (1.3 equiv), THF, $-78^{\circ} \mathrm{C}$ to $\mathrm{rt}, 3 \mathrm{~h}$ (80\%). DEAD diethyl azodicarboxylate, TBSCl $t$-butyldimethylsilyl chloride, LiHMDS lithium hexamethyldisilazide, THF tetrahydrofuran, DMF $\mathrm{N}, \mathrm{N}$-dimethylformamide intermediate A was proposed to be derived from the 5-6-6 tricyclic $\mathbf{D}$ by ring expansion. For the installation of the all-carbon quaternary stereocenter at the angular $\mathrm{C}_{6}$, we conceived of Birch reductive methylation from tricyclic ketone $\mathbf{E}$. To our knowledge, such transformation has never been explored in the synthesis of cyathane-type natural products presumably due to the concerns of annular strain, steric hindrance, and stereoselectivity ${ }^{1-3}$. However, the great potential to streamline the synthesis of cyathane compounds prompted us to investigate it. The construction of the crucial tricyclic system $\mathbf{F}$ might be achieved through an intramolecular Friedel-Crafts reaction of aldehyde $\mathbf{G}$ whose synthesis would be implemented through the Suzuki-Miyaura cross-coupling of a heavily substituted nonactivated vinyl triflate $\mathbf{H}$. Simplification of $\mathbf{H}$ revealed the five-membered cyclic ketone I, which was to be prepared through an enantioselective desymmetric reduction of 2,2-disubstituted 1,3-cyclopentanedione $\mathbf{J}$.

Synthesis of cyrneine A. The synthesis commenced with asymmetric synthesis of the cyclopentenyl triflate 15a (Fig. 3). Accordingly, allylation of the readily available 2-methyl 1,3cyclopentanedione 7 with allylic bromide 8 or 9 afforded 2,2disubstituted cyclopentanedione $\mathbf{1 0}$ and $\mathbf{1 1}$ in high yields, respectively. Desymmetric enantioselective reduction of $\mathbf{1 0}$ and 11 was carried out by CBS reduction ${ }^{21,22}$. However, the result was less satisfactory in terms of enantio- and diastereoselectivity, and scalability. We then inspected the enzyme-catalyzed reduction with baker's yeast ${ }^{23,24}$. Excellent enantioselectivity of up to $99 \%$ ee and moderate diastereoselectivity of ca. 8-9:1 were observed for 10. The imperfect diastereoselectivity prompted us to investigate the sterically more hindered $\mathbf{1 1}$. Delightedly, the d.r. ratio could be improved to ca. 25:1. Thus, a comparison of the results obtained from different ways showed that the enzyme-catalyzed reduction of prenyl substituted $\mathbf{1 1}$ afforded the best outcome. The reaction could be uneventfully performed on decagram scales to give $\alpha$-hydroxyketone $\mathbf{1 2}$ in $65-68 \%$ yield with $99 \%$ ee and $25: 1$ d.r. (see Supplementary Fig. 36). Configuration inversion of the

Table 1 Suzuki-Miyaura cross-coupling of $15 a$ and $16 a^{a}$

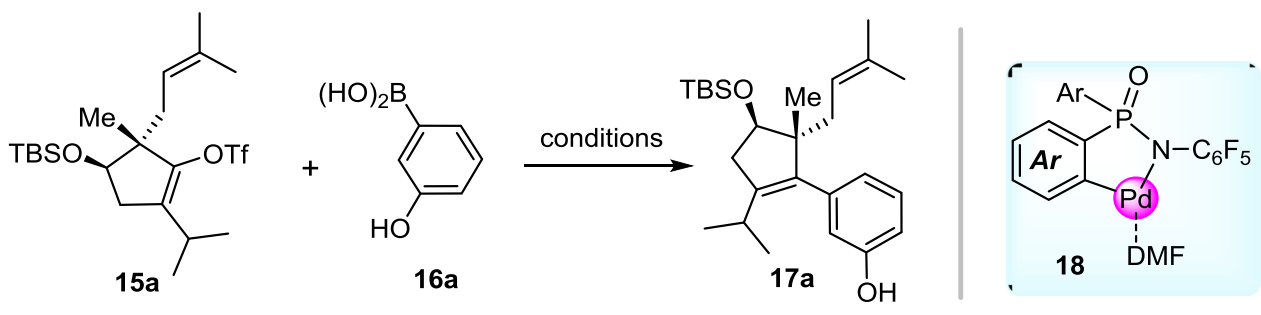

\begin{tabular}{|c|c|c|c|c|c|}
\hline Entry & Catalyst (5 mol\%) & Base (equiv) & Solvent & $T\left({ }^{\circ} \mathrm{C}\right)$ & Yield $(\%)^{b}$ \\
\hline 1 & $\mathrm{PdCl}_{2}(\mathrm{dppf})$ & $\mathrm{K}_{2} \mathrm{CO}_{3}$ & DMSO & 85 & 21 \\
\hline 2 & $\mathrm{Pd}\left(\mathrm{PPh}_{3}\right)_{4}$ & $\mathrm{~K}_{2} \mathrm{CO}_{3}$ & dioxane & 85 & 34 \\
\hline 3 & $\mathrm{Pd}\left(\mathrm{PPh}_{3}\right)_{4}$ & $\mathrm{~K}_{3} \mathrm{PO}_{4}$ & dioxane & 85 & 44 \\
\hline 4 & $\mathrm{Pd}(\mathrm{OAc})_{2} / \mathrm{dppp}$ & $\mathrm{K}_{2} \mathrm{CO}_{3}$ & dioxane & 85 & 33 \\
\hline 5 & $\mathrm{Pd}(\mathrm{OAc})_{2} / \mathrm{dppb}$ & $\mathrm{K}_{2} \mathrm{CO}_{3}$ & dioxane & 85 & 41 \\
\hline 6 & $\mathrm{PdCl}_{2} / \mathrm{dppp}$ & $\mathrm{K}_{2} \mathrm{CO}_{3}$ & dioxane & 85 & 22 \\
\hline 7 & $\mathrm{Pd}(\mathrm{OAc})_{2} / \mathrm{dppb}$ & $\mathrm{K}_{3} \mathrm{PO}_{4}$ & dioxane & 85 & 61 \\
\hline 8 & 18 & $\mathrm{~K}_{2} \mathrm{CO}_{3}$ & DMF/EtOH $(v / v=1: 1)$ & rt & $>99^{c}$ \\
\hline 9 & 18 & $\mathrm{~K}_{2} \mathrm{CO}_{3}$ & $\mathrm{DMF} / \mathrm{EtOH}(\mathrm{v} / \mathrm{v}=1: 1)$ & $r t$ & $95^{d}$ \\
\hline
\end{tabular}

aReaction conditions: 15a $(47.0 \mathrm{mg}, 0.1 \mathrm{mmol}), \mathbf{1 6 a}(27.6 \mathrm{mg}, 0.2 \mathrm{mmol})$, catalyst $(5 \mathrm{~mol} \%)$, and base (3.0 equiv), in $1 \mathrm{~mL}$ solvent under nitrogen atmosphere for $12 \mathrm{~h}$

b Isolated yield

The reaction was run at $\mathrm{rt}$ for $5 \mathrm{~h}$

${ }^{\mathrm{d}}$ The reaction was performed with $6.6 \mathrm{~g}$ of $\mathbf{1 5} \mathbf{a}$ and was quenched until $\mathbf{1 5} \mathbf{a}$ had disappeared as monitored by TLC 


\section{Table 2 Scope of substrates ${ }^{a}$}

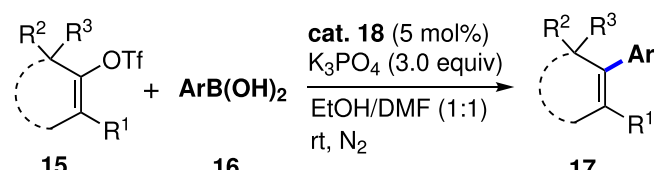

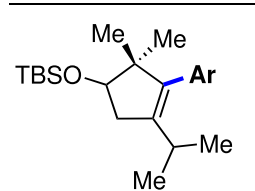

17b, $\mathrm{Ar}=p-\mathrm{OMeC}_{6} \mathrm{H}_{4}, 92 \%$

17c, $\mathrm{Ar}=p^{-}{ }^{\mathrm{t}} \mathrm{BuC}_{6} \mathrm{H}_{4}, 92 \% \mathrm{~b}^{\mathrm{b}}$

$17 \mathrm{~d}, \mathrm{Ar}=p-\mathrm{FC}_{6} \mathrm{H}_{4}, 94 \%$

$17 \mathrm{e}, \mathrm{Ar}=3,4,5-\mathrm{FC}_{6} \mathrm{H}_{2}, 92 \%{ }^{\mathrm{b}}$

$17 \mathrm{f}, \mathrm{Ar}=2$-furyl, $82 \%$

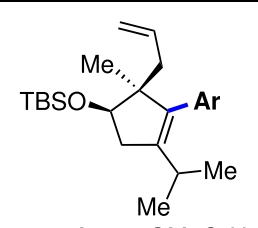

17g, $\mathrm{Ar}=p-\mathrm{OMeC}_{6} \mathrm{H}_{4}, 75 \%$

17h, $\mathrm{Ar}=p-{ }^{-} \mathrm{BuC}_{6} \mathrm{H}_{4}, 85 \%$

17i, $\mathrm{Ar}=3,4,5-\mathrm{FC}_{6} \mathrm{H}_{2}, 81 \%$

$17 \mathrm{j}, \mathrm{Ar}=2$-furyl, $85 \%$

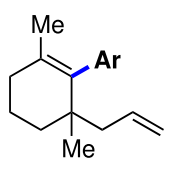

17o, $\mathrm{Ar}=p-\mathrm{OMeC}_{6} \mathrm{H}_{4}, 75 \%$

17p, $\mathrm{Ar}=p-\mathrm{MeC}_{6} \mathrm{H}_{4}, 83 \%$

$17 \mathbf{q}, \mathrm{Ar}=p-\mathrm{CF}_{3} \mathrm{C}_{6} \mathrm{H}_{4}, 70 \%$

$17 \mathrm{r}, \mathrm{Ar}=2$-benzofuryl, $81 \%$

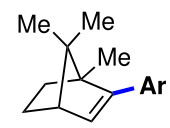

17s, $\mathrm{Ar}=p-\mathrm{OMeC}_{6} \mathrm{H}_{4}, 80 \%$

17t, $\mathrm{Ar}=p^{-}{ }^{\mathrm{t}} \mathrm{BuC}_{6} \mathrm{H}_{4}, 80 \%$

$17 \mathrm{u}, \mathrm{Ar}=p-\mathrm{CO}_{2} \mathrm{MeC}_{6} \mathrm{H}_{4}, 79 \%^{\mathrm{c}}$

$17 \mathrm{v}, \mathrm{Ar}=3,4,5-\mathrm{FC}_{6} \mathrm{H}_{2}, 75 \%$

$17 \mathrm{w}, \mathrm{Ar}=2$-furyl, $55 \%$

${ }^{a}$ Conditions: Enol triflate $\mathbf{1 5}(0.2 \mathrm{mmol})$, boronic acid $\mathbf{1 6}(0.4 \mathrm{mmol}), \mathrm{K}_{3} \mathrm{PO}_{4}(3.0$ equiv) in a mixed EtOH/DMF ( $\mathrm{v} / \mathrm{v}=1: 1)$ solvent $(2.0 \mathrm{~mL})$ at room temperature under nitrogen. Isolated yield. The use of $\mathrm{K}_{3} \mathrm{PO}_{4}$ instead of $\mathrm{K}_{2} \mathrm{CO}_{3}$ was more effective for the coupling of boronic acids without free phenol group

bThe yield was determined based on the ${ }^{1} \mathrm{H}$ NMR spectroscopy because of the contamination of a small amount of inseparable homocoupled product of boronic acid

${ }^{\mathrm{C}}$ The methyl ester group of the product was partially exchanged to ethyl ester

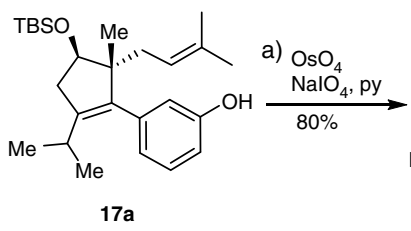<smiles>CC(C)C1=C(c2cccc(O)c2)[C@@](C)(C=O)C(OC(C)(C)C)C1</smiles>
b) $\mathrm{EtMgBr}$<smiles>[Y][14C]([14CH3])CC1CC1C</smiles>

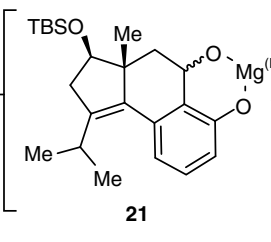

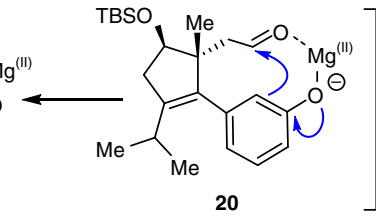

$\downarrow$ (chelation-control)

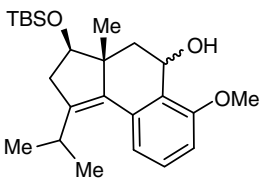

22 (ca.4.0 g)

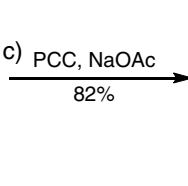<smiles>COc1cccc2c1C(=O)CC1(C)C2=C(C(C)C)CC1OC(C)C</smiles>

23 (ca.3.0 g)

Fig. 4 Synthesis of the tricyclic compound 23. Reagents and conditions: (a) $\mathrm{OsO}_{4}$ (4 mol\%), $\mathrm{NalO}_{4}$ (5.0 equiv), pyridine (3.0 equiv), dioxane $/ \mathrm{H}_{2} \mathrm{O}$ $(\mathrm{v} / \mathrm{v}=5: 1), 80^{\circ} \mathrm{C}(80 \%) ;($ b) $\mathrm{EtMgBr}$ (1.1 eqiuv, $1.0 \mathrm{M}$ in THF), -78 to 40 ${ }^{\circ} \mathrm{C}$, overnight, then $\mathrm{K}_{2} \mathrm{CO}_{3}$ (2.0 equiv), Mel (5.0 equiv), and DMF were charged in situ, $55^{\circ} \mathrm{C}, 10 \mathrm{~h}$ ( $72 \%$ ); (c) PCC (4.0 equiv), $\mathrm{NaOAc}$ (4.0 equiv), celite (ca. $130 \mathrm{wt} \%), \mathrm{rt}, 6 \mathrm{~h}$ (82\%). THF tetrahydrofuran, DMF N,Ndimethylformamide, PCC pyridinium chlorochromate

a-hydroxy group in $\mathbf{1 2}$ was carried out smoothly under Mitsunobu conditions to give the desired $\beta$-hydroxy intermediate 13. Protection of the $\beta$-hydroxy in 13 with TBS followed by a basemediated isopropylation with $i$ PrI provided ketone 14 in $80 \%$ yield over two steps ( $94 \%$ brsm). A literature survey showed that a-alkylation of ketone with secondary alkyl iodide was relatively difficult ${ }^{25,26}$. We examined the isopropylation under the effect of LDA, MHMDS $(\mathrm{M}=\mathrm{Li}, \mathrm{Na}, \mathrm{K})$, and $\mathrm{NaH}$, respectively. The results showed that $\mathrm{NaH}$ was a more efficient base. Treatment of 14 with LiHMDS and $\mathrm{PhNTf}_{2}$ afforded the enol triflate 15a.

The Suzuki-Miyaura cross-coupling involving sterically congested nonactivated enolate substrates was relatively rare. Initial scouting of the conditions for coupling triflate 15a with 16a was carried out by examining an array of conditions reported in literature ${ }^{27-31}$ (Table 1). Unfortunately, most of the reactions were less effective, affording the coupled product 17a in low yields (entries $1-6)$. While a combination of $\mathrm{Pd}(\mathrm{OAc})_{2}$ and $\mathrm{dppb}$ ligand could afford the product in moderate yield (entry 7), a large scale synthesis was problematic owing to an elongated reaction time, leading to partial hydrolysis of $\mathbf{1 5 a}$. To compare with the prior literature ${ }^{27-31}$, the low coupling efficiency is probably due to the excessively congested structure of 15a with the additional presence of a bulky OTBS. To overcome this obstacle, we turned to examine the catalytic efficiency of phosphinamide-derived palladacycle 18, which was developed in our previous studies toward synthesizing $\mathrm{P}$-stereogenic compounds through $\mathrm{C}-\mathrm{H}$ arylation of phosphinamide ${ }^{32,33}$ and exhibited excellent catalytic activity for Suzuki cross-coupling of aryl (pseudo)halides under mild conditions ${ }^{34}$. To our delight, we found that the palladacycle $\mathbf{1 8}$ did display high catalytic activity for such a heavily substituted nonactivated triflate 15a. The coupled product 17a could be obtained in almost quantitative yield at room temperature (entry 8). Most significantly, the reaction could be reliably scaled up to multigram scales ( $6.6 \mathrm{~g}$ of 15a) without compromising the yield (entry 9).

To further expand the potential utility of the new precatalyst for mild and effective coupling of sterically hindered nonactivated enolate derivatives, we examined the substrate scope by varying the structures of both reaction partners. Effective cross-coupling was observed for an extensive combination of an array of heavily substituted nonactivated enol triflates and aryl boronic acids. As shown in Table 2, both the five-membered (17b-17n) and sixmembered $(\mathbf{1 7 0}-\mathbf{1 7} \mathbf{r})$ cyclic enol triflates reacted smoothly with a rich range of aryl boronic acids whose structure was modified by electron-donating $\mathrm{OMe}, t \mathrm{Bu}$, and $\mathrm{Me}$, as well as electronwithdrawing $\mathrm{F}, 3,4,5$-trifluoro, $\mathrm{CF}_{3}$, and $\mathrm{CO}_{2} \mathrm{Me}$ groups. In addition, a [2.2.1]-bridged bicycle $(\mathbf{1 7} \mathbf{s}-\mathbf{1 7} \mathbf{w})$ also exhibited good 

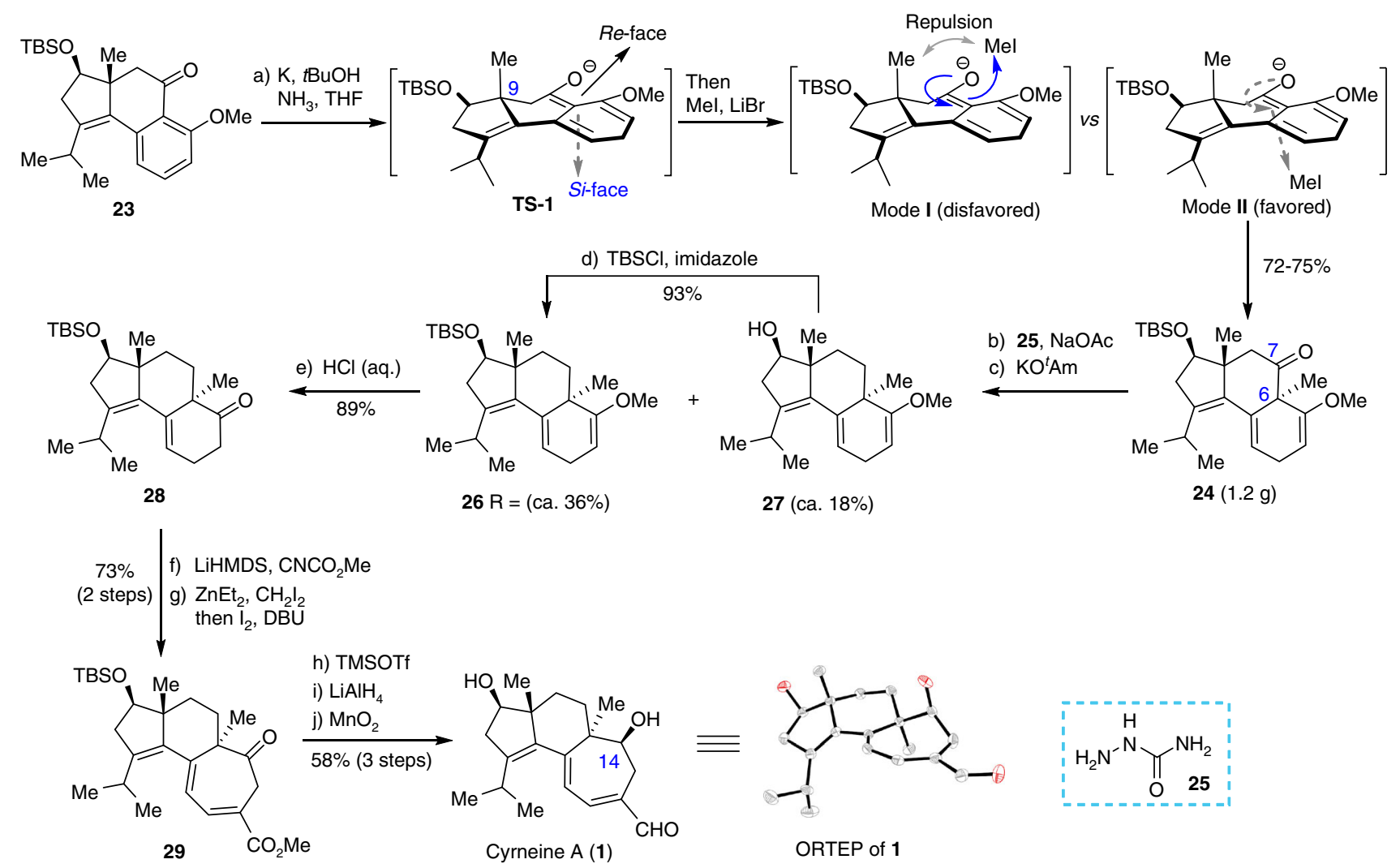

Fig. 5 The completion of the synthesis of cyrneine $A$. Reagents and conditions: (a) Liq. $\mathrm{NH}_{3}, t \mathrm{BuOH}\left(1.0\right.$ equiv), $\mathrm{K}\left(2.5\right.$ equiv), $\mathrm{Et}{ }_{2} \mathrm{O},-78^{\circ} \mathrm{C}, 10$ min; then $\mathrm{LiBr}$ (2.5 equiv), Mel (5.0 equiv), and THF were charged in situ, $-78^{\circ} \mathrm{C}, 1 \mathrm{~h}$, then warmed to rt over a period of $1 \mathrm{~h}$ (72\%); (b) 25 (5.0 equiv), $\mathrm{NaOAc}(5.0$ equiv), $\mathrm{EtOH}, 35^{\circ} \mathrm{C}, 3 \mathrm{~h}$; (c) $\mathrm{KOtAm}$ ( 5.0 equiv), degassed xylene, $140{ }^{\circ} \mathrm{C}, 1.8 \mathrm{~h}$ ( $36 \%$ for $\mathbf{2 6} ; 18 \%$ for 27); (d) $\mathrm{TBSCl}(1.2 \mathrm{equiv}$ ), imidazole (1.2 equiv),

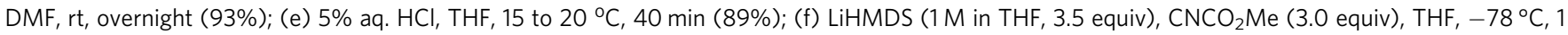
$\mathrm{h} ;$ (g) $\mathrm{ZnEt}_{2}$ (1.0 M in hexane, 6.0 equiv), $\mathrm{CH}_{2} \mathrm{I}_{2}$ (6.0 equiv), $\mathrm{CH}_{2} \mathrm{Cl}_{2}, \mathrm{rt}, 2 \mathrm{~h} ; \mathrm{I}_{2}$ (7.0 equiv), rt; then saturated aq. $\mathrm{Na}_{2} \mathrm{~S}_{2} \mathrm{O}_{3}$ (excess), rt; then DBU (20.0 equiv), rt, 10 min ( $73 \%$ for 2 steps); (h) TMSOTf (5.0 equiv), $\mathrm{CH}_{2} \mathrm{Cl}_{2},-25^{\circ} \mathrm{C}, 15 \mathrm{~min}$; (i) $\mathrm{LiAlH}_{4}\left(6.0\right.$ equiv), Et ${ }_{2} \mathrm{O}, 10$ min at $-78{ }^{\circ} \mathrm{C}$, then warmed to rt; (j) $\mathrm{MnO}_{2}$ (50 equiv), $\mathrm{CH}_{2} \mathrm{Cl}_{2}$, rt, overnight (58\% in 3 steps); tAm = tert-amyl; DBU =1,8-diazabicyclo[5.4.0]undec-7-ene; TMSOTf = trimethylsilyl trifluoromethanesulfonate

compatibility. Notably, the reaction was viable for 2 -furyl and benzo-2-furyl boronic acids $(\mathbf{1 7} \mathbf{f}, \mathbf{1 7} \mathbf{j}, \mathbf{1 7} \mathbf{n}, \mathbf{1 7} \mathbf{r}$, and $\mathbf{1 7 w})$. These results would be appealing because coupling of 2-heteroaryl boronic acids is a considerable challenge resulting from the detrimental pyrolysis under conventional heating conditions ${ }^{35}$, especially with the nonactivated enol triflates as seen from the sporadic examples explored in the synthesis of relevant natural products ${ }^{36}$.

Having established the robust conditions for large scale synthesis of $17 \mathrm{a}$ in this way, we then shifted our focus to construct the 5-6-6 tricarbocyclic system 23 (Fig. 4). Oxidation of the double bond in 17a delivered the aldehyde 19. For the Friedel-Crafts cyclization of 19 , we first examined the acidmediated protocols as investigated in Trost's ${ }^{28}$ and Jiang ${ }^{37}$ synthesis of hamigeran B. However, similar to their outcome, the reaction proved to be futile owing to multiple difficulties associated with the poor regioselectivity of para vs. ortho to phenolic $\mathrm{OH}$, the lability of OTBS group, and the ease of further dehydration of the cyclized product. After a careful deliberation, we devised a chelation-controlled strategy and found that $\mathrm{EtMgBr}$ was a suitable reagent. Namely, treatment of 19 with $\mathrm{EtMgBr}$ produced a magnesium phenolate salt. The $\mathrm{Mg}$ (II) ion may be acting to serve as a Lewis acid to coordinate with the aldehyde group, and thereby forming intermediate $\mathbf{2 0}$ through chelationcontrol. Consequently, the Friedel-Crafts reaction proceeded exclusively at the position ortho to phenolic $\mathrm{OH}$ to afford the tricyclic product 21. Upon in situ selective methylation of phenolic $\mathrm{OH}$, the tricyclic alcohol 22 could be obtained as a single regioisomer in $64-72 \%$ yield on multigram scales. Oxidation of $\mathbf{2 2}$ gave the corresponding ketone $\mathbf{2 3}$ smoothly.

Next, our task was moved forward to complete the synthesis of cyrneine A (1) (Fig. 5). Attempted installation of methyl group at $\mathrm{C}_{6}$ in 23 was carried out by executing the Birch reductive methylation. However, initial trials showed that the reaction was considerably challenging. Only a complex mixture was afforded under a broad array of conditions. Based on the NMR analysis of the crude products, the reaction was mainly complicated by the competitive reduction of $\mathrm{C}_{3}=\mathrm{C}_{4}$ double bond, aryl ring, and carbonyl group without observation of the methylated product. After an exhaustive screening and optimization of conditions, we could successfully install the angular methyl group based on the methods reported early by Narisada ${ }^{38}$ and Gibbard $^{39}$. It was found that addition of scrupulously dried $\mathrm{LiBr}$ was crucial. The desired product 24 could be obtained in $72-75 \%$ yield as a single diastereoisomer over gram scale. The exceptionally high stereoselectivity is presumably attributed to the steric hindrance of methyl group at $\mathrm{C}_{9}$, which compels the nucleophilic attack of TS1 anion to MeI to take place from the less hindered si-face as illustrated by mode I versus mode II. The stereochemistry of $\mathbf{2 4}$ was determined by NOESY correlations (see Supplementary Fig. 21) and was further confirmed by X-ray single crystal analysis of the final product (vide infra).

Concerning the reduction of the carbonyl functionality in the central ring of 24, many unexpected obstacles were encountered. 

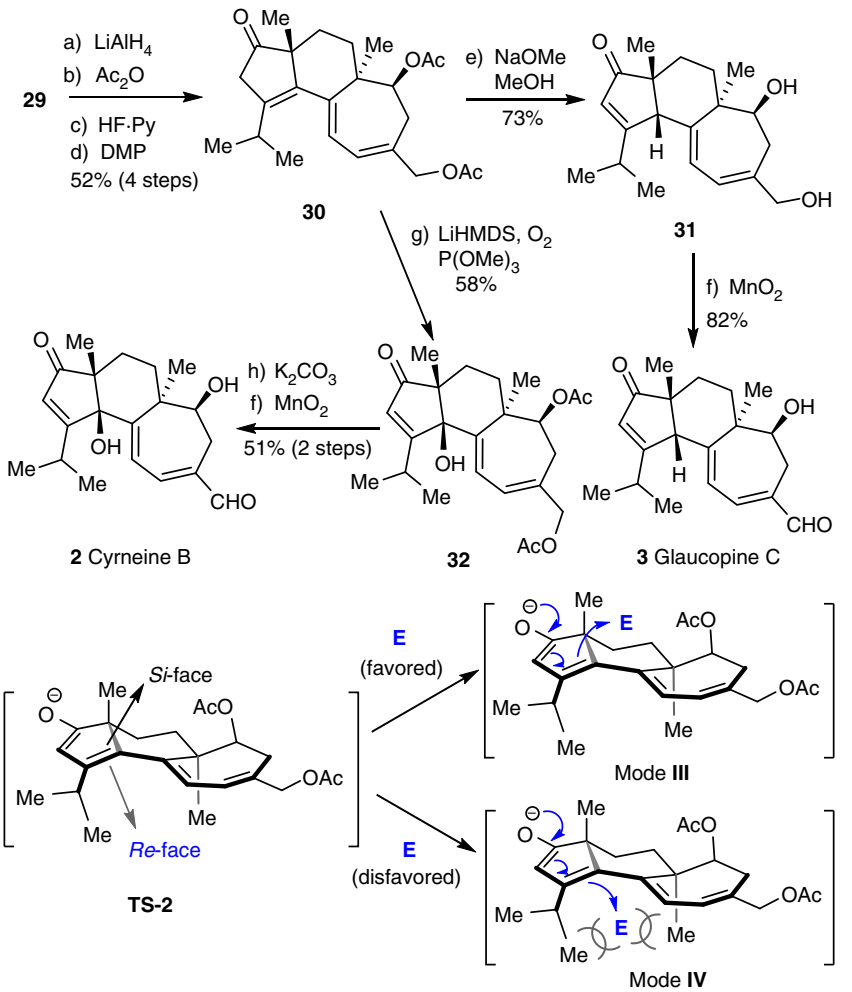

Fig. 6 The synthesis of cyrneine $B$ and glaucopine $C$. Reagents and conditions: (a) $\mathrm{LiAlH}_{4}$ (6.0 equiv), $\mathrm{Et}_{2} \mathrm{O}, 20 \mathrm{~min}$ at $-78^{\circ} \mathrm{C}$, then warmed to rt; (b) $\mathrm{Ac}_{2} \mathrm{O}$ (15.0 equiv), DMAP (20 mol\%), pyridine, $30 \mathrm{~min}, \mathrm{rt}$; (c) HF•Py (excess), THF, rt, $2 \mathrm{~h}$; (d) DMP (1.6 equiv), $\mathrm{CH}_{2} \mathrm{Cl}_{2}, 30 \mathrm{~min}$, rt (52\% for 4 steps); (e) $\mathrm{NaOMe}, \mathrm{MeOH}, 35^{\circ} \mathrm{C}, 4 \mathrm{~h}$ (73\%); (f) $\mathrm{MnO}_{2}$ (15 equiv), $\mathrm{CH}_{2} \mathrm{Cl}_{2}, \mathrm{rt}, 3 \mathrm{~h}$ (82\%); (g) LiHMDS (2.0 equiv), THF, $-78^{\circ} \mathrm{C}, 15 \mathrm{~min}$, then $\mathrm{P}$ $(\mathrm{OMe})_{3}$ (4.0 equiv), $\mathrm{O}_{2}, 2 \mathrm{~h}(58 \%) ;(\mathrm{h}) \mathrm{K}_{2} \mathrm{CO}_{3}$ (excess), $\mathrm{MeOH}, 35^{\circ} \mathrm{C}, 4 \mathrm{~h}$ ( $51 \%$ for 2 steps). DMAP 4-(dimethylamino)pyridine, Py pyridine, DMP Dess-Martin periodinane

First, we examined the Barton-McCombie ${ }^{40}$ radical reduction involving reduction of the carbonyl group $\left(\mathrm{NaBH}_{4}, \mathrm{MeOH}\right)$, thiocarbonation of hydroxy $\left(\mathrm{NaH}, \mathrm{CS}_{2}, \mathrm{MeI}\right)$, and radical induced deoxygenation. However, the product $\mathbf{2 6}$ was obtained in lower than $20 \%$ yield under a free combination of various radical initiators (e.g., $\mathrm{AIBN}, \mathrm{ABCN}, \mathrm{Et}_{3} \mathrm{~B}$,) and reductants (e.g., $\mathrm{Bu}_{3} \mathrm{SnH}$, TMSH, TTMSS, and $\left.\mathrm{Ph}_{2} \mathrm{SiH}_{2}\right)$. Although no vigorous proof, it seemed that the cleavage of $\mathrm{C}_{6}-\mathrm{C}_{7}$ bond occurred facilely under radical conditions. Alternatively, the Wolff-Kishner-Huang type reduction was also proved to be ineffective under an array of routine conditions ${ }^{41-48}$. Extensive decomposition of substrate was observed. Fortunately, a patient investigation revealed that the reaction of 24 with semicarbazide $25^{49,50}$ followed by treatment of the resulting semicarbazone with KOtAm in degassed xylene afforded 26 in ca. $36 \%$ yield accompanied by ca. $18 \%$ of desilylated 27 , which could be resilylated to give $\mathbf{2 6}$. As a result, $\mathbf{2 6}$ could be obtained in $53 \%$ yield in a synthetically useful level. Hydrolysis of the vinyl ether in $\mathbf{2 6}$ gave ketone 28, which was immediately subjected to the ring expansion reaction without careful purification since 28 was somewhat easily oxidized under ambient atmosphere. For ring expansion, Nakada in the synthesis of allocyathin $\mathrm{B}_{2}{ }^{2}$ employed a four-step sequence involving acylation, iodomethylation, $\mathrm{SmI}_{2}$ promoted ring expansion, and $\mathrm{LDA} / \mathrm{I}_{2}$-meidated elimination. Inspired by a protocol of Zercher ${ }^{51}$, we accomplished the conversions through a two-step operation involving acylation followed by a one-pot $\mathrm{Zn}$ carbenoid-mediated ring expansion and $\mathrm{I}_{2}$-promoted elimination. Compound 29 was thus obtained efficiently in $73 \%$ yield over two steps. Finally, elaboration of $\mathbf{2 9}$ by removal of TBS, simultaneous reduction of ketone and ester, and selective oxidation of allylic primary alcohol furnished the total synthesis of cyrneine A (1) in 58\% yield over three steps. Notably, the reduction proceeded highly stereoselectively at $\mathrm{C}_{14}$ to afford $\beta-\mathrm{OH}$ product. The structure of $\mathbf{1}$ was unambiguously confirmed by ${ }^{1} \mathrm{H}$ - and ${ }^{13} \mathrm{C}-\mathrm{NMR}$, HRMS, and single crystal X-ray (CCDC 1830226) analysis. The data and dextrorotary property of the final product matched well with those of the reported natural sample ${ }^{16}$ (See Supplementary Table 1 and 2, and Supplementary Fig. 26).

Synthesis of cyrneine B and glaucopine C. Having successfully synthesized cyrneine A, we entered the final stage toward synthesizing cyrneine B (2) and glaucopine C (3) (Fig. 6). Based on our retrosynthetic design, the advanced intermediate 29 was converted into $\beta, \gamma$-enone 30 through four routine transformations. After an optimization of reaction sequence and conditions, we found that the 1,3-prototropic shift and concomitant deprotection of acetyl in $\mathbf{3 0}$ proceeded smoothly under the effect of $\mathrm{NaOMe}$ to deliver the thermodynamically preferred enone $\mathbf{3 1}$ as a single $\mathrm{C}_{4} \quad \beta-\mathrm{H}$ stereoisomer. The stereochemistry was determined by NOESY correlation (see Supplementary Fig. 29). The exceptionally good stereoselectivity is presumably resulted from the differential steric hindrance between $r$-face and $s i$-face of TS-2. As a result, the enolate anion prefers to approach the electrophiles from the less congested si-face rather than the hindered $r e$-face (i.e., mode III vs. IV). Subsequently, selective oxidation of the allylic primary alcohol completed the synthesis of glaucopine C (3). Encouraged by the highly stereo- and regioselective prototropic shift, the installation of $\mathrm{C}_{4} \beta$-hydroxy toward synthesizing cyrneine $\mathrm{B}$ (2) was carried out though a base-mediated prototropic shift and aerobic $\gamma-\mathrm{CH}$ oxidation cascade from 30. While a complex mixture with high polarity was obtained in initial scouting of the conditions under the effect of weak bases and heating presumably due to over oxidation of olefins and acidic $\mathrm{CH}$ at $\mathrm{C}_{2}$ and $\mathrm{C}_{18}$, treatment of 30 with LiHMDS by lowering the temperature to $-78^{\circ} \mathrm{C}$ under $\mathrm{O}_{2}$ atmosphere afforded $\mathbf{3 2}$ in $58 \%$ yield. Finally, removal of acetyl followed by selective oxidation of the allylic alcohol delivered cyrneine B (2). The structures of cyrneine B and glaucopine C were confirmed by various spectroscopic analyses and by comparison of the analytical data of the synthetic samples with those reported for natural products ${ }^{16,19}$ (see Supplementary Table 3-6, and Supplementary Fig. 30-35).

\section{Discussion}

In summary, we have developed an efficient route that allowed for a more step-economic total synthesis of cyrneine A (20 steps), and the first total synthesis of cyrneine B (24 steps) and glaucopine C (23 steps) from readily available commercial materials. The synthesis features the use of a mild and efficient Suzukicoupling of heavily substituted nonactivated vinyl triflate, a $\mathrm{Mg}$ (II)-mediated chelation-controlled Friedel-Crafts cyclization, a Birch reductive methylation, and a zinc carbenoid-mediated ring expansion. These key transformations enable an efficient and rapid construction of the 5-6-7 tricyclic core. Finally, the divergent synthesis of the three natural products from this core is achieved through several carefully orchestrated manipulations involving a stereoselective reduction of $\mathrm{C}_{14}$ carbonyl, a stereoselective 1,3-prototropic shift, and a stereo- and chemoselective prototropic shift $/ \gamma-\mathrm{CH}$ oxidation cascade at $\mathrm{C}_{4}$. The utility of the new strategy and methods for efficient and flexible synthesis of other structurally relevant products is currently underway. 


\section{Methods}

Procedures for the synthesis of cyrneines A-B and glaucopine $\mathbf{C}$. The detailed experimental procedures for the synthesis of cyrneines A, B, and glaucopine $C$ were provided in Supplementary Information.

\section{General procedure for the cross-coupling reaction of enol triflates. To} solution of vinyl triflate $\mathbf{1 5}(0.2 \mathrm{mmol})$ in a mixed solvent of DMF $(1.0 \mathrm{~mL})$ and EtOH $(1.0 \mathrm{~mL})$ was added arylboronic acid $16(0.4 \mathrm{mmol}, 2.0$ equiv), palladacycle 18 (5.6 mg, $5 \mathrm{mmol} \%$ ), and $\mathrm{K}_{3} \mathrm{PO}_{4}\left[127 \mathrm{mg}, 0.6 \mathrm{mmol}\right.$, 3.0 equiv $\left(\mathrm{K}_{2} \mathrm{CO}_{3}\right.$ was used for the coupling of $\mathbf{1 5 a}$ with $\mathbf{1 6 a}$ )] at room temperature under nitrogen atmosphere. The resulting mixture was stirred at the same temperature until the vinyl triflate had disappeared as monitored by TLC. The reaction mixture was then poured into water and extracted with ethyl acetate $(3 \times 25 \mathrm{~mL})$. The organic layer was combined, washed with brine, dried over $\mathrm{Na}_{2} \mathrm{SO}_{4}$, and concentrated under vacuum. The residue was purified by silica gel column chromatography to afford the desired cross-coupling product 17

Data availability. Chemical compound information including NMR and HRMS data, copies of ${ }^{1} \mathrm{H}$ - and ${ }^{13} \mathrm{C}-\mathrm{NMR}$ of all new compounds, $2 \mathrm{D}$ NMR of compounds 24, 31, cyrneine B (2), and glaucopine (3), HPLC charts for compound 12, and single X-ray crystal data of cyrneine A (1). This material is provided in Supplementary Information. The X-ray crystallographic coordinates for cyrneine A (1) reported in this study have also been deposited at the Cambridge Crystallographic Data Centre (CCDC), under deposition number 1830226. These data can be obtained free of charge from The Cambridge Crystallographic Data Centre via www.ccdc.cam.ac.uk/data_request/cif. Other supporting data related to this work are available from the corresponding author upon reasonable request.

Received: 21 February 2018 Accepted: 24 April 2018

Published online: 01 June 2018

\section{References}

1. Enquist, J. A. Jr \& Stoltz, B. M. Synthetic efforts toward cyathane diterpenoid natural products. Nat. Prod. Rep. 26, 661-680 (2009).

2. Nakada, M. Enantioselective total synthesis of cyathane diterpenoids. Chem Rec. 14, 641-662 (2014).

3. Tang, H.-Y., Yin, X., Zhang, C.-C., Jia, Q. \& Gao, J.-M. Structure diversity, synthesis, and biological activity of cyathane diterpenoids in higher fungi. Curr. Med. Chem. 22, 2375-2391 (2015)

4. Ward, D. E., Gai, Y. \& Qiao, Q. A general approach to cyathin diterpenoids. Total synthesis of allocyathin B3. Org. Lett. 2, 2125-2127 (2000).

5. Ward, D. E. \& Shen, J. Enantioselective total synthesis of cyathin $\mathrm{A}_{3}$. Org. Lett. 9, 2843-2846 (2007).

6. Trost, B. M., Dong, L. \& Schroeder, G. M. Total synthesis of (+)-allocyathin B . J. Am. Chem. Soc. 127, 2844-2845 (2005).

7. Trost, B. M., Dong, L. \& Schroeder, G. M. Exploiting the Pd- and Ru-catalyzed cycloisomerizations: enantioselective total synthesis of $(+)$-allocyathin $\mathrm{B}_{2}$. J. Am. Chem. Soc. 127, 10259-10268 (2005).

8. Waters, S. P., Tian, Y., Li, Y.-M. \& Danishefsky, S. J. Total synthesis of (-)-scabronine G, an inducer of neurotrophic factor production. J. Am. Chem. Soc. 127, 13514-13515 (2005).

9. Enquist, J. A. Jr \& Stoltz, B. M. The total synthesis of $(-)$-cyanthiwigin F by means of double catalytic enantioselective alkylation. Nature 453, 1228-1231 (2008).

10. Pfeiffer, M. W. B. \& Phillips, A. J. Total synthesis of $(+)$-cyanthiwigin U. J. Am. Chem. Soc. 127, 5334-5335 (2005).

11. Reddy, T. J., Bordeau, G. \& Trimble, L. Total synthesis of $(+)$-cyanthiwigin AC. Org. Lett. 8, 5585-5588 (2006)

12. Snider, B. B., Vo, N. H., O'Neil, S. V. \& Foxman, B. M. Synthesis of ( \pm )-allocyathin $\mathrm{B}_{2}$ and $(+)$-erinacine A. J. Am. Chem. Soc. 118, 7644-7645 (1996).

13. Snider, B. B., Vo, N. H. \& O’Neil, S. V. Synthesis of ( \pm )-allocyathin $B_{2}$ and (+)-erinacine A. J. Org. Chem. 63, 4732-4740 (1998).

14. Tori, M., Toyoda, N. \& Sono, M. Total synthesis of allothathin $\mathrm{B}_{2}$, a metabolite of bird's nest fungi. J. Org. Chem. 63, 306-313 (1998).

15. Piers, E., Gilbert, M. \& Cook, K. L. Total synthesis of the cyathane diterpenoid ( \pm )-sarcodonin G. Org. Lett. 2, 1407-1410 (2000).

16. Marcotullio, M. C., Pagiotti, R. \& Maltese, F. et al. Neurite outgrowth activity of cyathane diterpenes from Sarcodon cyrneus, cyrneine A and B. Planta Med. 72, 819-823 (2006).

17. Marcotullio, M. C., Pagiotti, R. \& Maltese, F. et al. Cyathane diterpenes from Sarcodon cyrneus and evaluation of their activities of neuritegenesis and nerve growth factor production. Bioorg. Med. Chem. 15, 2878-2882 (2007).
18. Obara, Y., Hoshino, T., Marcotullio, M. C., Pagiotti, R. \& Nakahata, N. A novel cyathane diterpene, cyrneine $\mathrm{A}$, induces neurite outgrowth in a Rac1-dependent mechanism in PC12 cells. Life Sci. 80, 1669-1677 (2007).

19. Marcotullio, M. C., Pagiotti, R. \& Campagna, V. et al. Glaucopine C, a new diterpene from the fruiting bodies of Sarcodon glaucopus. Nat. Prod. Res. 20 917-921 (2006).

20. Elamparuthi, E., Fellay, C., Neuburger, M. \& Gademann, K. Total synthesis of cyrneine A. Angew. Chem. Int. Ed. 51, 4071-4073 (2012).

21. Shimizu, M., Yamada, S., Fujita, Y. \& Kobayashi, F. Highly stereocontrolled reduction of 1,3-cyclopentanediones using oxazaborolidine- $\mathrm{BH}_{3}$. Tetrahedron.: Asymmetry 11, 3883-3886 (2000).

22. Liu, L. L. \& Chiu, P. An expeditious asymmetric synthesis of the pentacyclic core of the cortistatins by an intramolecular $(4+3)$ cycloaddition. Chem. Commun. 47, 3416-3417 (2011).

23. Csuk, R. \& Glaenzer, B. I. Baker's yeast mediated transformations in organic chemistry. Chem. Rev. 91, 49-97 (1991).

24. Brooks, D. W., Mazdiyasni, H. \& Grothaus, P. G. Asymmetric microbial reduction of prochiral 2,2-disubstituted cycloalkanediones. J. Org. Chem. 52, 3223-3232 (1987)

25. Kraft, P. \& Popaj, K. New musk odorants: (3E)-4-(2'-alkyl-5',5' dimethylcyclopent-1'-enyl)but-3-en-2-ones and (3E)-1-acetyl-3-alkylidene4,4-dimethylcyclohexenes. Eur. J. Org. Chem. 4806-4814 (2008).

26. Cornella, J., Jackson, E. P. \& Martin, R. Nickel-catalyzed enantioselective C-C bond formation through $\mathrm{C}_{\mathrm{sp}}{ }^{2}-\mathrm{O}$ cleavage in aryl esters. Angew. Chem. Int. Ed. 54, 4075-4078 (2015).

27. Willis, M. C., Claverie, C. K. \& Mahon, M. F. Tandem intermolecular Suzuki coupling/intramolecular vinyl triflate-aryl coupling. Chem. Commun. 0, 832-833 (2002)

28. Trost, B. M., Pissot-Soldermann, C. \& Chen, I. A short and concise synthesis of hamigeran B. Chem. Eur. J. 11, 951-959 (2005).

29. Occhiato, E. G., Galbo, F. L. \& Guarna, A. Preparation and Suzuki-Miyaura coupling reactions of tetrohydropyridine-2-boronic acid pinacol esters. J. Org. Chem. 70, 7324-7330 (2005).

30. Baxter, J. M., Steinhuebel, D., Palucki, M. \& Davies, I. W. Stereoselective eno tosylation: preparation of trisubstituted $\alpha, \beta$-unsaturated esters. Org. Lett. 7, 215-218 (2005).

31. Li, X., Xue, D., Wang, C. \& Gao, S. Total synthesis of the hamigerans. Angew. Chem. Int. Ed. 55, 9942-9946 (2016).

32. Du, Z.-J., Guan, J., Wu, G.-J., Xu, P., Gao, L.-X. \& Han, F.-S. Pd(II)-catalyzed enantioselective synthesis of P-stereogenic phosphinamides via desymmetric $\mathrm{C}-\mathrm{H}$ arylation. J. Am. Chem. Soc. 137, 632-635 (2015).

33. Guan, J., Wu, G.-J. \& Han, F.-S. Pd ${ }^{\mathrm{II}}$-catalyzed mild C-H ortho arylation and intramolecular amination oriented by a phosphinamide group. Chem. Eur. J. 20, 3301-3305 (2014).

34. Wu, G.-J., Han, F.-S. \& Zhao, Y.-L. Palladacycles derived from arylphosphinamides for mild Suzuki-Miyaura cross-couplings. RSC Adv. 5, 69776-69781 (2015)

35. Kinzel, T., Zhang, Y. \& Buchwald, S. L. A new palladium precatalyst allows for the fast Suzuki-Miyaura coupling reactions of unstable polyfluorophenyl and 2-heteroaryl boronic acids. J. Am. Chem. Soc. 132, 14073-14075 (2010).

36. Kuang, L., Liu, L. L. \& Chiu, P. Formal total synthesis of $(+)$-cortistatins A and J. Chem. Eur. J. 21, 14287-14291 (2015).

37. Jiang, B., Li, M.-M., Xing, P. \& Huang, Z.-G. A concise formal synthesis of (-)-hamigeran B. Org. Lett. 15, 871-873 (2013).

38. Narisada, M. \& Watanabe, F. Reductive alkylation of monoaromatic ketones. J. Org. Chem. 38, 3887-3892 (1973).

39. Gibbard, H. C., Moody, C. J. \& Rees, C. W. 3aH-indenes. Part 5. Preparation and reactions of 3-methoxy- and 3-trimethylsiloxy-3a-substituted-3aHindenes. J. Chem. Soc. Perkin Trans. 1, 0, 723-729 (1985)

40. Crich, D. \& Quintero, L. Radical chemistry associated with the thiocarbonyl group. Chem. Rev. 89, 1413-1432 (1989).

41. Toyota, M., Wada, T. \& Ihara, M. Total synthesis of (-)-methyl atis-16-en-19 oate, (-)-methyl kau-16-en-19-oate, and (-)-methyl trachyloban-19-oate by a combination of palladium-catalyzed cycloalkenylation and homoallylhomoallyl radical rearrangement. J. Org. Chem. 65, 4565-4570 (2000).

42. Marino, J. P., Rubio, M. B., Cao, G. \& de Dios, A. Total synthesis of $(+)$-aspidospermidine: a new strategy for the enantiospecific synthesis of aspidosperma alkaloids. J. Am. Chem. Soc. 124, 13398-13399 (2002).

43. Peterli-Roth, P., Maguire, M. P., León, E. \& Rapoport, H. Synthesis of 6-deaminosinefungin and (S)-6-methyl-6-deaminosinefungin. J. Org. Chem. 59, 4186-4193 (1994)

44. Hutchins, R. O., Milewski, C. A. \& Maryanoff, B. E. Selective deoxygenation of ketones and aldehydes including hindered systems with sodium cyanoborohydride. J. Am. Chem. Soc. 95, 3662-3668 (1973).

45. Thompson, C. F., Jamison, T. F. \& Jacobsen, E. N. Total synthesis of FR901464. Convergent assembly of chiral components prepared by asymmetric catalysis. J. Am. Chem. Soc. 122, 10482-10483 (2000). 
46. Klahn, P., Duschek, A., Liébert, C. \& Kirsch, S. F. Total synthesis of (+)-cyperolone. Org. Lett. 14, 1250-1253 (2012).

47. Paquette, L. A., Wang, T.-Z. \& Vo, N. H. Access to naturally occurring cyclooctanoids by two-carbon intercalation. Total synthesis of (+ )-ceroplastol I. J. Am. Chem. Soc. 115, 1676-1683 (1993).

48. Hayashida, J. \& Rawal, V. H. Total synthesis of ( \pm )-platencin. Angew. Chem. Int. Ed. 47, 4373-4376 (2008).

49. Nakajima, R., Ogino, T., Yokoshima, S. \& Fukuyama, T. Total synthesis of (-)-mersicarpine. J. Am. Chem. Soc. 132, 1236-1237 (2010).

50. Grundon, M. F., Henbest, H. B. \& Scott, M. D. The reactions of hydrazones and related compounds with strong bases. Part I. A modified Wolff-Kishner procedure. J. Chem. Soc. 0, 1855-1858 (1963).

51. Lin, W. \& Zercher, C. K. Formal synthesis of $(+)$-brefeldin A: application of a zinc-mediated ring expansion reaction. J. Org. Chem. 72, 4390-4395 (2007).

\section{Acknowledgements}

We thank Prof. Bao-Min Wang at Dalian University of Technology for helpful discussions on the revision of the manuscript. Financial support from NSFC (21572215,

21602215), and State Key Laboratory of Fine Chemicals (KF 1515) is acknowledged.

\section{Author contributions}

F.S.H. conceived the synthetic strategy, directed the project, and wrote the manuscript. F. S.H. and G.J.W. analyzed the experiment results. G.J.W., Y.H.Z. and D.X.T. conducted the experimental work.

\section{Additional information}

Supplementary Information accompanies this paper at https://doi.org/10.1038/s41467018-04480-6.

Competing interests: The authors declare no competing interests.

Reprints and permission information is available online at http://npg.nature.com/ reprintsandpermissions/

Publisher's note: Springer Nature remains neutral with regard to jurisdictional claims in published maps and institutional affiliations.

cc (i) Open Access This article is licensed under a Creative Commons Attribution 4.0 International License, which permits use, sharing, adaptation, distribution and reproduction in any medium or format, as long as you give appropriate credit to the original author(s) and the source, provide a link to the Creative Commons license, and indicate if changes were made. The images or other third party material in this article are included in the article's Creative Commons license, unless indicated otherwise in a credit line to the material. If material is not included in the article's Creative Commons license and your intended use is not permitted by statutory regulation or exceeds the permitted use, you will need to obtain permission directly from the copyright holder. To view a copy of this license, visit http://creativecommons.org/ licenses/by/4.0/.

(C) The Author(s) 2018 